\title{
Effects of Pinching Time on the Performance of three Tomato Varieties (Lycopersicon lycopersicum Mill) in Ogbomoso and Mokwa, Nigeria
}

\author{
Tswanya M.N. ${ }^{*}$, Olaniyi J.O. ${ }^{2}$, Akanbi W.B. ${ }^{2}$, Kolawole G.O. ${ }^{2}$ \\ ${ }^{1}$ Biotechnology Advanced Research Centre, Sheda Science and Technology Complex, P.M.B. 186, Garki-Abuja \\ 2 Department of Agronomy, Faculty of Agricultural Sciences, Ladoke Akintola \\ University of Technology, P.M.B 4000, Ogbomoso, Oyo State, Nigeria.
}

\begin{abstract}
Field experiment was conducted at the Teaching and Research Farm, Ladoke Akintola University of Technology, Ogbomoso and Niger State College of Agriculture, Mokwa, in 2012 cropping season to examine the effects of pinching on fruit yield and nutritional qualities of three tomato varieties. The experiment had twelve treatments of three varieties (Ogbomoso Local, Mokwa Local and UC82B) of tomato and four pinching times (0, 2, 4 and 6) weeks after transplanting (WAT), replicated three times. The experiment was laid out as split plot arranged in Randomized Complete Block Design. Data were collected on plant height, number of flowers, number of fruits and total fruit yield. The determination of fruit phytochemical contents at full ripening, 6 fruit samples were randomly selected per plot and analysed for nutritional qualities such as crude Protein, Carotene, Iron, Phosphorus, Potassium, Calcium, Lycopene, Magnesium, Vitamin C contents. Data was analysed using analysis of variance (ANOVA) SAS package and treatment means compared using least significant difference (LSD) at 5\% probability level.
\end{abstract}

There were varietal differences in fresh fruit yield among the three varieties of tomato. UC82B gave the highest fruit yield (23.10 $t \mathrm{ha}^{-1}$ ) while Mokwa Local recorded the

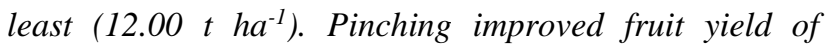
tomato. Plants pinched at 4 WAT gave the highest fruit yield $\left(19.60 t \mathrm{ha}^{-1}\right)$ and the least obtained from unpinched plants $\left(12.50 \mathrm{t} \quad \mathrm{ha}^{-1}\right)$. Nutritional qualities (Lycopene, phosphorus, potassium) was best at PT of 6 WAT. It could be concluded from this experiment that, though highest yield of tomato (19.60 $\left.t \mathrm{ha}^{-1}\right)$ occurred with pinching at 4 WAT, the best nutritional qualities were obtained when pinched at 6 WAT. Also, UC82B was better than other varieties in terms of yield performance. Keywords - Tomato, pinching time, variety, nutritional quality.

\section{INTRODUCTION}

Tomato (Lycopersicon lycopersicum) belongs to the solanaceae family. It originated in Peru and Mexico, in the present day Central and South America from where it spread to other parts of the world (Zeidan, 2005). Tomato reached Europe from Mexico in the $16^{\text {th }}$ century, and was initially used as ornamental plant. Its cultivation for edible fruits started at the end of the $18^{\text {th }}$ century. Tomato was introduced to West Africa and Nigeria in particular, at the end of the $19^{\text {th }}$ century (Villareal, 1980). It is currently considered to be one of the main vegetable crops in the world, and constitutes an economic force that influences the income of many growers in the world (Omar, 2005). In Nigeria tomato also finds its way into almost every kitchen. Tomato crop is very important in terms of diet and economy in Nigeria both during the rainy season (rainfed) and dry season using irrigation facilities. It is used as a condiment in stews and soup or eaten raw in salads. Industrially, the crop is made into puree, sauce, paste and powder (Balarabe, 2012).

Tomato is a rich source of nutrients. Fresh tomatoes and tomato juices are high in water, low in calories and rich in Vitamin C (Kocchar, 1981). It is a good source of vitamin $\mathrm{A}$, and it is cholesterol free. Similarly, canned tomatoes contain about 3-4 times the vitamin $\mathrm{C}$ content of fresh ripe tomatoes. Ripe tomatoes contain 3-4 times the vitamin $\mathrm{A}$ as mature green tomatoes, but otherwise tomato varieties are about equal in nutritional value. Tomato puree and plain types of tomato sauce without added ingredients such as meat or mushrooms have about twice the solids content and about double the nutritional value of fresh tomatoes and tomato juice. Tomato paste, which has about four times the solids content of fresh tomatoes, is a concentrated source of nutrients, making it a valuable ingredient when used in preparation of food (Iris and David, 2001). New medical research suggests that the consumption of lycopene - the stuff that gives 
tomato its red colour - may prevent cancer (Balarabe, 2012).

Presently, there are tomato cultivars and hybrids which can be cultivated in the climate different from the site of origin and which could also serve as sources of genes for improvement of adapted varieties. However, commercial cultivation of tomatoes in Nigeria exhibits seasonality with much of the production concentrated in the relatively cool and dry period under irrigation or in the 'fadama'. Furthermore, yields of the varieties of the tropics are generally low compared with yields obtained in the temperate region (McGraw et al., 1992; Anon, 1992; Surya, 1993). Although the use of improved varieties along with fertilizer application have increased tomato production in the tropics, the full potential of the crop has not been achieved when compared to the temperate countries where fruits yield could be as high as $52.8 \mathrm{t} \mathrm{ha}^{-1}$ (FAO, 2000). The low yield of $10 \mathrm{t} \mathrm{ha}^{-1}$ obtained in the tropics has been attributed to several factors including high temperatures, high humidity, excessive rainfall (FAO, 2006; Opena et al., 1989), diseases and insect pests (Tee et al., 1979; Ma, 1985), lack of appropriate varieties (Villareal, 1979; Olaniyi and Ojetayo, 2010) and cultural practices (Znidarcic et al., 2003).

Many of the tomato varieties grown in Nigeria belong to the group that exhibits indeterminate growth. Studies in other places like the United States of America have shown that members of this group are known to respond positively to apical bud removal and branch pinching. Pinching is an horticultural operation in which the terminal growing end of a plant is removed. Pinched plants produce multiple terminal growths that bear flowers and hence increase fruit formation (George, 2004). In addition, apical and lateral buds pinching have been reported to result in the production of bigger fruits in tomato (Frank, 2012). Also, pinched plant produced larger fruit two to three weeks earlier than un-pinched plant (Michele, 2009). However, despite the importance of this operation there is limited information on the response of the cultivars grown in Nigeria to pinching.

Despite many investigations in the area of nutrition, knowledge on how pinching influences physical and phytochemical contents of tomato fruit is insufficient. This study determined plant growth, physical and nutritional qualities of three tomato varieties in Ogbomoso and Mokwa, Nigeria as influenced by pinching times.

\section{MATERIALS AND METHODS}

The experiment was conducted at two locations; Teaching and Research Farm, Ladoke Akintola University of Technology, Ogbomoso $\left(8^{\circ} 10^{1} \mathrm{~N} ; 4^{\circ} 10^{1} \mathrm{E}\right)$ and Niger State College of Agriculture, Mokwa $\left(9^{\circ} 18^{1} \mathrm{~N}\right.$ and $\left.5^{\circ} 04^{1} \mathrm{E}\right)$, during 2012 cropping season. The experimental plot was ploughed and harrowed after which lining out was carried out. There were 36 plots with three replications. Each replicate consisted of 12 plots. Each treatment was in a plot size of $2.5 \mathrm{~m} \times 2.0 \mathrm{~m}\left(5.0 \mathrm{~m}^{2}\right)$. A plot contained 30 plants. The total experimental area was $378.00 \mathrm{~m}^{2}(0.038$ $\left.\mathrm{ha}^{-1}\right)$. The alley way between replicates plots was $1.0 \mathrm{~m}$ and within replicates was $1.0 \mathrm{~m}$. Tomato seedlings were transplanted at a spacing of $50 \mathrm{~cm} \times 50 \mathrm{~cm}$. The treatments consisted of four pinching times; 0 (no pinching) 2, 4 and 6 weeks after transplanting (WAT) and three tomato varieties (Ogbomoso Local, Mokwa Local and UC82B). The treatments were laid out as split plot arranged in Randomized Complete Block Design, replicated three times.

The seeds were sourced from the Department of Crop Production and Soil Science, Ladoke Akintola University of Technology, Ogbomoso and from the Department of Agricultural Technology, Niger State College of Agriculture, Mokwa. The tomato seeds were sown on nursery beds containing pulverized soil and the seedlings were raised for four weeks before transplanting to the field at the two locations. Watering in the nursery was done as at when needed. Healthy and vigorous seedlings were transplanted into the field in order to ensure uniformity. Watering was done using watering - can to supplement rainfall. Pesticide in form of cypermethrin was applied at the dosage of $25 \mathrm{ml}$ per 15 litres of knapsack sprayer fortnightly to check caterpillars, worms and grasshoppers. Manual weeding was also carried out using hoe at three weeks interval starting from 2 WAT to reduce competition between weeds and plants. Data were collected on plant height, number of flowers, number of fruits and total fruit yield. The determination of fruit phytochemical contents at full ripening, 6 fruit samples were randomly selected per plot and analysed for nutritional qualities such as crude Protein, Carotene, Iron, Phosphorus, Potassium, Calcium, Lycopene, Magnesium, Vitamin $\mathrm{C}$ contents. In order to assess these, 6 fruit samples were collected and dried in an oven at $85^{\circ} \mathrm{C}$ for 72 hours. The dried fruit samples were separately ground with a Wiley mill, and passed through a $0.5 \mathrm{~mm}$ sieve for tissue analysis. Total $\mathrm{P}$ was determined by the Vanadomolybdate method, $\mathrm{K}$ and $\mathrm{Ca}$ was determined by the flame photometry and $\mathrm{Mg}$ and Fe were determined by atomic absorption spectrophotometer (IITA, 1989). Total $\mathrm{N}$ was analyzed by the micro-Kjeldahl procedure as described by IITA (1989) and crude protein was obtained by multiplying the total $\mathrm{N}$ by a factor of 6.25. Data collected were subjected to Analysis of Variance (ANOVA) using SAS statistical package. Treatment means were separated using the least significant difference (LSD) at 5\% probability level. 


\section{RESULTS}

Plant height (cm)

The plant heights of the tomato varieties were not significantly $(\mathrm{P} \leq 0.05)$ different at 2 and 4 WAT but at 6 WAT variety UC82B was significantly shorter than Ogbomoso Local and Mokwa Local which were not significantly different from each other (Table 1).

The plants pinched at 2 weeks were significantly shorter $(13.0 \mathrm{~cm})$ than the plants from the un-pinched plants and pinched plants at 6 weeks. The un-pinched plants recorded the highest mean value of $39.5 \mathrm{~cm}$ at $6 \mathrm{WAT}$. But the value obtained from un-pinched was not significantly different from the mean value $(37.1 \mathrm{~cm})$ obtained from the plants pinched at 6 weeks. The trend was the same at 2, 4 and 6 WAT. The interaction effect of variety and pinching time had no significant $(\mathrm{P} \geq 0.05)$ effect on the plant height of tomato at all the sampling periods.

\section{Number of flowers}

The number of flowers of UC82B (30.3) was significantly $(\mathrm{P} \leq 0.05)$ more than that of Ogbomoso Local (22.3) which was not more than that of Mokwa Local (21.3). The mean number of flowers of three tomato varieties were significantly $(\mathrm{P} \leq 0.05)$ increased by the pinching time. The plants pinched at 4 WAT recorded the highest mean value of 31.6, followed by the pinched plants at 6 WAT with the mean value of 26.0 which was not significantly different from the plants pinched at 2 WAT (22.3) while the least mean value of 18.7 was obtained from the control plot. But there was no significant difference between the plants pinched at 2 WAT and the control plots (Table 2).

\section{Number of fruits per plant}

The number of fruits of UC82B (30.5) was significantly higher than that of Ogbomoso Local (22.3) while the varieties of Ogbomoso Local and Mokwa Local had similar number of fruits (Table 3 ). The number of fruits was significantly $(\mathrm{P} \leq 0.05)$ increased by pinching time. The plants pinched at 4 WAT recorded the highest mean value of 31.8 which was significantly higher than the mean value of 26.0 obtained at 6 WAT. But there was no significant difference between the mean values received at 6 WAT from the plants pinched at 2 weeks and the control plot. The interaction effect between the variety and pinching time was not significant $(\mathrm{P} \geq 0.05)$.

\section{Total fruit yield $\left(\mathbf{t} \mathbf{h a}^{-1}\right)$}

The three tomato varieties was significantly $(\mathrm{P} \leq 0.05)$ different in the total fruit yield (Table 4). The highest fruit yield of $23.10 \mathrm{t} \mathrm{ha}^{-1}$ was obtained from UC82B, followed by the mean value of $14.60 \mathrm{t} \mathrm{ha}^{-1}$ received from Ogbomoso Local which was not significantly different from the least mean value of $12.00 \mathrm{t} \mathrm{ha}^{-1}$ obtained from Mokwa Local. But UC82B significantly performed better than the values obtained from Ogbomoso Local and Mokwa Local varieties, respectively.

Pinching time had significant $(\mathrm{P} \leq 0.05)$ influence on the total fruit yield of tomato. The total fruit yield increased as the pinching time weeks increased with the highest mean value of $19.60 \mathrm{t} \mathrm{ha}^{-1}$ recorded from the plants pinched at 4 WAT. This was closely followed by the plants pinched at 6 WAT with the mean value of $18.00 \mathrm{t}$ $\mathrm{ha}^{-1}$. The plants pinched at 4 WAT significantly recorded a higher yield than the plants pinched at 2 WAT and the un-pinched, respectively. Also, the plants pinched at 2 WAT with the mean value of $16.10 \mathrm{t} \mathrm{ha}^{-1}$ significantly gave better yield than that of the control plot which had the least mean value of $12.50 \mathrm{t} \mathrm{ha}^{-1}$. The interactive effect of variety and pinching time was not significant $(\mathrm{P} \geq 0.05)$.

\section{Crude protein, Carotene and Iron contents}

The nutritional content of three tomato varieties were significantly $(\mathrm{P} \leq 0.05))$ influenced by variety and pinching time except for carotene and iron contents (Table 5). The nutritional content increased as the plant aged and as the pinching time increased (Table 20). Protein content of UC82B $(1.1 \mathrm{mg} / 100 \mathrm{~g})$ was significantly $(\mathrm{P} \leq 0.05)$ higher than that of Ogbomoso Local $(1.0 \mathrm{mg} / 100 \mathrm{~g})$ but was not significantly different from Mokwa Local $(1.1 \mathrm{mg} / 100 \mathrm{~g})$. The carotene and iron contents were not significantly $\mathrm{P}>0.05$ ) influenced.

The protein content was not significantly $(\mathrm{P} \leq 0.05)$ increased by pinching time and interaction effect of variety and pinching time was also not significant. The carotene content was not significantly $(\mathrm{P} \geq 0.05)$ increased by variety but was significantly $(\mathrm{P} \leq 0.05)$ influenced by pinching time. The tomato plants pinched at 4 and $6 \mathrm{WAT}$ recorded the highest mean value $(0.4 \mathrm{mg} / 100 \mathrm{~g})$ which was significantly higher than that of the plants pinched at 2 WAT $(0.3 \mathrm{mg} / 100 \mathrm{~g})$ and were also higher than that of the control plot. The interaction effect of variety and pinching time was not significant $(\mathrm{P} \leq 0.05)$. The variety, pinching time and their interaction had no significant $(\mathrm{P} \geq 0.05)$ influence on iron content.

\section{Phosphorus, Potassium and Calcium contents}

The phosphorus content of Ogbomoso Local $(7.6 \mathrm{mg} / 100$ g) was significantly $(\mathrm{P} \leq 0.05)$ higher than that of UC82B $(7.1 \mathrm{mg} / 100 \mathrm{~g})$ which was also significantly higher than that of Mokwa Local $(6.6 \mathrm{mg} / 100 \mathrm{~g})$. Pinching time effect significantly $(\mathrm{P} \leq 0.05)$ increased phosphorus content. The plants pinched at 4 WAT gave the highest mean value of $7.5 \mathrm{mg} / 100 \mathrm{~g}$, closely followed with the mean value of 7.4 
$\mathrm{mg} / 100 \mathrm{~g}$ obtained at 6 WAT which was significantly higher than the plants pinched at 2 WAT $(7.0 \mathrm{mg} / 100 \mathrm{~g})$ and the least mean value of $6.5 \mathrm{mg} / 100 \mathrm{~g}$ was obtained from the control plots. The interactive effect of variety and pinching time was significant $(\mathrm{P} \leq 0.05)$ with the highest mean value $(8.1 \mathrm{mg} / 100 \mathrm{~g})$ received from Ogbomoso Local at 4 WAT.

The potassium content of Mokwa Local $(5.6 \mathrm{mg} / 100 \mathrm{~g}$ ) was significantly $(\mathrm{P} \leq 0.05)$ higher than that of UC82B (5.3 $\mathrm{mg} / 100 \mathrm{~g}$ ) which was significantly higher than that of Ogbomoso Local (4.9 mg/100 g), respectively. Also, the potassium content was significantly $(\mathrm{P} \leq 0.05)$ increased by pinching time. The plants pinched at $4 \mathrm{WAT}$ recorded the highest mean value $(5.8 \mathrm{mg} / 100 \mathrm{~g})$ which significantly produced better than the plants pinched at 6 WAT $(5.7$ $\mathrm{mg} / 100 \mathrm{~g}$ ) and was significantly higher than the pinched plants at $2 \mathrm{WAT}$. The least mean value $(4.4 \mathrm{mg} / 100 \mathrm{~g})$ was received from the control plot. The interaction effect between variety and pinching time was not significant $(\mathrm{P} \leq 0.05)$.

The calcium mineral content of UC82B $(10.0 \mathrm{mg} / 100 \mathrm{~g})$ was significantly $(\mathrm{P} \leq 0.05)$ higher than the mean values $(8.9 \mathrm{mg} / 100 \mathrm{~g}$ and $8.6 \mathrm{mg} / 100 \mathrm{~g}$ ) received from Ogbomoso Local and Mokwa Local, respectively. The calcium content was significantly $(\mathrm{P} \leq 0.05)$ influenced by pinching time. The plants pinched at 4 WAT (10.3 $\mathrm{mg} / 100 \mathrm{~g}$ ) was significantly higher than that of the plants pinched at 2 WAT $(8.7 \mathrm{mg} / 100 \mathrm{~g})$ and the least mean value $(7.9 \mathrm{mg} / 100 \mathrm{~g})$ was observed from the control plot. There was significant $(\mathrm{P} \leq 0.05)$ interaction effect of variety and pinching time. The highest mean value (10.7 $\mathrm{mg} / 100 \mathrm{~g}$ ) was obtained from UC82B at 4 WAT (Table $6)$.

\section{Lycopene, Magnesium and Vitamin $C$ contents}

The lycopene content was not significantly $(\mathrm{P} \geq 0.05)$ influenced by variety, pinching time and their interaction (Table 7). Magnesium content was not significantly $(\mathrm{P} \geq 0.05)$ influenced by variety. However, it was significantly $(\mathrm{P} \leq 0.05)$ increased by pinching time. The plants pinched at 6 WAT produced the highest magnesium content with the mean value $(0.8 \mathrm{mg} / 100 \mathrm{~g})$ observed from the plants pinched at 4 and 6 WAT while the least mean value $(0.5 \mathrm{mg} / 100 \mathrm{~g})$ was obtained from the control plot. The interaction effect of variety and pinching time was not significant $(\mathrm{P} \geq 0.05)$.

More so, vitamin C content of UC82B (32.3 mg/100 g) was significantly $(\mathrm{P} \leq 0.05)$ higher than Ogbomoso Local and Mokwa Local which had the mean values (30.0 and $29.7 \mathrm{mg} / 100 \mathrm{~g})$, respectively. The vitamin C mineral content was significantly ( $\mathrm{P} \leq 0.05)$ influenced by pinching time. The plants pinched at 4 WAT recorded the highest mean value $(32.8 \mathrm{mg} / 100 \mathrm{~g})$ which was not significantly different from the plants pinched at 6 WAT and was significantly higher than that of 2 WAT $(30.1 \mathrm{mg} / 100 \mathrm{~g})$. While the least mean value $(28 \mathrm{mg} / 100 \mathrm{~g})$ was obtained from the un-pinched plants. The interaction effect of variety and pinching time was not significant $(\mathrm{P} \geq 0.05)$.

\section{DISCUSSION}

The increased in growth parameters as the plant aged might be due to the increase in the cell number and size. This result is similar to the report of Olaniyi and Akanbi (2008) who reported that there was increase in the plant height and number of leaves of cabbage as the plant aged. The significant reduction in plant height following pinching time as recorded in the current study agrees with the report of Stacey (1983) in which apical bud removal resulted in decreased tomato plant height. The results of the current study revealed that plants in which pinching time of 2 and 4 WAT were done had decreased plant height. This is in agreement with the findings of the above author. Findings in this study also agrees with those of Levent and Sozer (2001) who stated that pinching of the lateral branches and the tips cause reduction in the production of a mass foliage which must have led to plant height reduction observed in the presents study. This is contrary to the reports of Uddin et al. (1997) and Ara et al. (2007) working in Bangladesh who obtained the shortest heights from un-pruned tomato plants. The disagreement might have arisen from varietal and climatic differences. Olasantan (2001) also reported that treatment that enhanced in branch production increased young leaf production in okra. Greater branch number must have translated to increase leaf area which must have increased plant height significantly. Expectedly, un-pinched plant height significantly have more number of aborted flowers than other treatments due to the fact that they were the tallest which agrees with the report of Babik (1982) who stated that taller plants may encourage flower abortion easily. The significant increase in number of flowers is as a result of more lateral buds that were encouraged to develop when plants tip were pinched. This agrees with George (2004) who revealed that pinched plants produced multiple terminal growths that bore flowers and hence, increased fruit formation and size. Stopping of tomato plants above six or seven trusses is a practice that encourages flowering (Michele, 2009). However, result obtained from this study in which about 30.3 flowers was obtained for UC82B, agrees with Anon. (2008) and Tswanya et al. (2012) who stated that average number of tomato flowers ranged between 20 - 35 under normal practice. The results showed that the pinched plants at 2, 4 and 6 WAT produced more flowers and fruits than unpinched plants. In the present study, pinching time at 2, 4 and 6 WAT produced fruits that were significantly bigger 
than the control plants. This agrees with the observations of Tonya (2006) who reported that fruits formed on unpinched tomato plants are generally smaller than that of pinched ones. In okra, work carried out by Olasantan and Salau (2007) also revealed that pruning significantly increased number of pods per plant.

The superiority of UC82B over the other two varieties in respect of the number of flowers and total fruit yield agrees with the findings of Olaniyi (2009) who stated that tomato varieties differ in flowering ability due to differences in genetic make-up. This view is also in line with that of Olaniyi and Fagbayide (1999). The results of the current study showed that UC82B significantly gave the highest total fruit yield of $23.10 \mathrm{t} \mathrm{ha}^{-1}$ which falls to the upper value of a range of $26.29 \mathrm{t} \mathrm{ha}^{-1}$ of the world as reported by FAO (2003) and 20 to $30 \mathrm{t} \mathrm{ha}^{-1}$ with good management as reported by Uguru (2011). Furthermore, the highest total fruit yield of $19.60 \mathrm{t} \mathrm{ha}^{-1}$ and $18.00 \mathrm{t} \mathrm{ha}^{-1}$ was recorded when plants were pinched at 4 WAT than the values obtained from the un-pinched plants, which was very close to 20 to $30 \mathrm{t} \mathrm{ha}^{-1}$ total tomato yield reported by Uguru (2011). These yield values obtained from this current study agrees with the findings of Tswanya et al. (2012) who revealed that plants pinched produces higher fruit yield than the un-pinched plants.

The significant increase in the fruit nutritional qualities parameters which pinching time treatment was imposed showed the potentials involved in tomato varieties. The nutritional composition increased as the pinching time periods increased up to 6 WAT. The result obtained from this present study is in agreement with the findings of Olaniyi et al. (2010). There was no consistency in the nutritional qualities obtained in this current study for the tomato varieties used. UC82B variety closely followed by Mokwa Local significantly recorded higher nutritional qualities than the other variety. The result of this study is in line with the findings of Olaniyi et al. (2010) who confirmed that there was inconsistence in the nutritional values obtained in their study for the tomato varieties used. Ara et al. (2007) supported the result obtained in this study that tomato is a dependable source of Vitamin $\mathrm{A}, \mathrm{B}, \mathrm{C}$ and D, minerals, $\mathrm{Ca}, \mathrm{P}$ and Fe. Result of the nutritional qualities revealed that tomato fruits are rich in phosphorus, potassium, calcium and vitamin C. This might be the reason of their intensive use for stew in meals.

\section{CONCLUSIONS}

In conclusion, pinching time at 4 WAT improved fruit yield and nutritional quality of tomato and UC82B performed better than other varieties. Generally, the values observed from un-pinched plots were lower than the pinched plants. It was observed that UC82B gave the highest fruit yield and consistently maintained higher values in other parameters evaluated. Also, the best nutritional qualities were obtained from UC82B at the pinching time of 4 WAT.

\section{REFERENCES}

[1] Anon (2008). A guide to production of some vegetables (NIHORT) extension guide No. 10.

[2] Anon (1992). Tomato yield production improved by the organic kind of farming. USDA Publication.

[3] Ara, N; Bashar, M.K; Begun, S. and Kakon, S.S. (2007). Effect of spacing and stem pruning on the growth and yield of tomato. International Journal of Sustainable Crop production, 2 (3):35 -39.

[4] Babik, S. (1982) Effect of pruning and decapitating on the earliness of tomatoes grown in heated plastic tunnels. Biuletyn Warzy Wniczy, Poland. Pp. 201212.

[5] Balarabe, S. (2012). Tomato production in Nigeria: issues and prospects. Ministry of Agriculture and Rural Development Kano, Kano State.

[6] FAO, (2000). Traditional Food Plants in Rome. Pp. 10.

[7] FAO, (2003). Food and Agricultural Organization of the United Nations, soil survey project in Bangladesh, Soil Res. Tech. Rep. Volume 57. Pp. $140-141$.

[8] FAO, (2006). Food and Agriculture organization of the United Nations. Food Security Statistics Nigeria.

[9] Frank, F. (2012). Managing tomato plants for better health and better fruit. http: //www. Vegeteblegardener.com (assessed October 20 2012). George, A. (2004). Horticuture principles and practices. Published by Asoke K. Pp. $709-710$.

[10] IITA (1989). Automated and semi-automated methods for soil and plant analysis. Manual series No. 7. IITA, Ibadan, Nigeria.

[11] Iris, E.P. and David, M.S. (2001). History, Origin and Early Cultivation of Tomato. USDA. Agricultural Research Service, Vegetable Crops Research Unit, University of Wisconsin, USA.

[12] Kocchar, S. H. (1981). Vegetable Production in the Tropics. Published by Longman Group Limited London. Pp. 230.

[13] Levent, A. and Ankara, S. (2001). Effect of lowtunnel, mulch and pruning on the yield and earliness of tomato in unheated glasshouse. Journal of Applied Horticulture, 3 (1): 23-27.

[14] Ma, J.H. (1985). Varietal trials on tomato. Training report of the $3^{\text {rd }}$ Regional Training programme in vegetable production and Research, Thailand. 
[15] McGraw, M.G.O. and Raphael, T.U. (1992). Quality of four cultivars of cherry tomatoes. Pp.32-34.

[16] Michele T. (2009). Minnesota Gardening. ForumGarden web. Pinching off tomatoes. http://www.bioone.org. (assessed May 6 2009).

[17] Olaniyi, J.O. (2009). Evaluation of yield and quality performance of grain Amaranth varieties in the Southern western Nigeria. Resource Journal of Agronomy, 1 (2): 42-45.

[18] Olaniyi, J.O., Akanbi, W. B. (2008). Effects of cultural practices on mineral compositions of cassava peel compost and its effects on the performance of cabbage (Brassica oleracea L.). Journal of Applied Biosciences, volume 8 (1): 272 279.

[19] Olaniyi, J.O. and Fagbayide, J.A. (1999). Performance of eight F1 Hybrid Cabbage (Brassica oleracea L.) varieties in the Southern Guinea Savanna Zone of Nigeria. Journal of Agricultural Biotechnology and Environment, 1: 4-10.

[20] Olaniyi, J.O., Akanbi, W. B., Adejumo, T. A., Akande, O. G. (2010). Growth, fruit yield and nutritional quality of tomato varieties. African Journal of Food Science, 4 (6): 398 -402.

[21] Olaniyi, J.O. and Ojetayo, A.E. (2010). The effect of organomineral and inorganic fertilizers on the growth, fruit yield and quality of pepper (Capsicum frutescence). Journal of Animal and plant sciences, 8 (3): 1070-1076.

[22] Olasantan, F. O. (2001). Optimum plant populations for Okra (Abelmoschus esculentus) in a mixture with cassava (Manihot esculenta and maize (zea mays) in south-western Nigeria. Journal of Agricultural Science, 136: 207-214.

[23] Olasantan F.O. and Salau A.W. (2007). Effect of pruning on growth, leaf yield and pod yield of okra (Abelmoschus esculentus (L.) Moench.). Journal of Agricultural Science, 146: 93-102.

[24] Omar, Z. (2005). Tomato production under protected conditions. Published by Mashav, Cinad co and the peres center for peace project coordinator. Pp. 71112.

[25] Opena, R.T., Green, S.K., Talekar, N.S. and Chen, J.C. (1989). Genetic improvement of tomato adaptability to the tropics. Progress and future prospects. Tomato and pepper production in the tropics. Asian Vegetable research and development centre, Shanhua, Tainan, Taiwan. Pp.70-75.
[26] Stacey, D. L. (1983). The effect of artificial defoliation on the yield of tomato plants and its relevance to pest damage. Journal of Horticultural Science, 58: 117-120.

[27] Surya, P.B. (1993). Nitrogen effect on fruit set, yield and quality of heat tolerant tomato. Training Report in ARC-AVRDC, Kasetsart University, Bangkok, Thailand. Pp.121-124.

[28] Tee, T.S., Villareal, R.L. and Rejab, M. (1979). Single seed descent: A new approach to the improvement of tomato in the tropics. Proceedings of the first international symposium on tropical tomato. AVRDC), Shanhua, Tainan, Taiwan. Pp. 225.

[29] Tonya, S. (2006). Practicing home and garden. How to prune tomatoes / How to do things.

http://www.howtodothings.com/home-and-garden. (assessed February 92007).

[30] Tswanya, M.N., Oladiran, J.A., Isah, K.M., Lile, S.N. and Yisa, P.Z. (2012). Effect of stopping and pruning on growth and seed yield of four tomato varieties (Lycopersicon esculentum Mill) in the Southern Guinea Savanna of Nigeria. International Journal of Agricultural and Development Economic, Volume 2: 112-124.

[31] Uddin. M. R., Hossain, M. A., Mian, M. A. K., Uddin, M. Z. R. and Mahtabuddin, A.K.M. (1997) Effect of stem pruning and spacing on the growth and yield obtained in the shortest height of tomato. Bangladesh Horticulture, 25 (1 and 2): 41-46.

[32] Uguru, M. I. (2011). Crop Production Tools, Techniques and Practice. Department of Crop Science, University of Nigeria, Nsukka. Pp. 144.

[33] Villareal, R.L. (1980). Tomato in the tropics. West view Press Boulder, Colorado. Pp. 174.

[34] Villareal, R.L. (1979). Tomato production in the tropics: problems and progress $1^{\text {st }}$ International Symposium on Tropical Tomato. Robert Cowell Asian Vegetable research and Development centre, Shanhua, Tainan, Taiwan.

[35]Zeidan, O. (2005). Tomato production under protected condition. Ministry of Agriculture and Rural Development. The center for International Agriculture Development Cooperation. Pp. 43-44.

[36]Znidarcic, D.S.T. and Zlatic (2003). Impact of growing methods on tomato (Lycopersicon esculentum Mill) yield and sensory quality. University of Ljublj Knert, 81 (2): 341-348. 
Table.1: Effect of variety, pinching time and their interaction on plant height of tomato plants in 2012 cropping season

\begin{tabular}{|c|c|c|c|c|c|}
\hline \multirow[b]{3}{*}{ Variety } & \multicolumn{5}{|c|}{ Plant Height $(\mathrm{cm})$} \\
\hline & \multicolumn{5}{|c|}{ Pinching Time (WAT) } \\
\hline & 0 & 2 & 4 & 6 & Variety Mean \\
\hline & & & $2 \mathrm{WA}$ & & \\
\hline OL & 16.8 & 13.8 & 15.3 & 15.7 & 15.4 \\
\hline ML & 14.9 & 12.1 & 13.5 & 14.3 & 14.6 \\
\hline UC82B & 15.6 & 13.2 & 13.6 & 14.8 & 14.5 \\
\hline PT Mean & 15.8 & 13.0 & 14.1 & 14.9 & \\
\hline
\end{tabular}

PT 1.21

$\mathrm{V} \times \mathrm{PT} \quad \mathrm{ns}$

$\begin{array}{llllll}\text { OL } & 21.9 & 19.5 & 19.8 & 21.6 & 20.7 \\ \text { ML } & 19.8 & 17.3 & 18.7 & 19.4 & 19.9 \\ \text { UC82B } & 20.6 & 17.3 & 18.7 & 20.1 & 19.7 \\ \text { PT Mean } & 20.8 & 18.0 & 19.1 & 20.4 & \end{array}$

$\begin{array}{ll}\text { LSD:V } & \mathrm{ns} \\ \text { PT } & 1.22 \\ \text { V x PT } & n s\end{array}$

\begin{tabular}{llllll} 
OL & \multicolumn{4}{c}{ 6 WAT } \\
ML & 43.0 & 35.7 & 38.4 & 39.9 & 39.3 \\
UC82B & 39.9 & 35.4 & 37.9 & 38.8 & 38.7 \\
PT Mean & 35.6 & 30.0 & 31.5 & 32.5 & 36.9 \\
\hline
\end{tabular}

$\begin{array}{ll}\text { LSD:V } & \mathrm{ns} \\ \mathrm{PT} & 3.01 \\ \mathrm{~V} \times \mathrm{PT} & \mathrm{ns}\end{array}$

$\mathrm{OL}=\frac{\mathrm{V} \times \mathrm{PT}}{=}$ Ogbomoso local, $\mathrm{ML}=$ Mokwa local, $\mathrm{PT}=$ pinching time, $\mathrm{V}=$ variety, $\mathrm{ns}=$ not significant $(\mathrm{P} \leq 0.05), \mathrm{LSD}=$ least significant difference

Table.2: Effect of variety, pinching time and their interaction on number of flowers per plant of tomato plant in 2012 cropping season

\begin{tabular}{|c|c|c|c|c|c|c|}
\hline \multirow[b]{3}{*}{ Variety } & \multicolumn{5}{|c|}{ Number of flowers } & \\
\hline & \multirow[b]{2}{*}{0} & \multicolumn{2}{|c|}{ Pinching time (WAT) } & \multirow[b]{2}{*}{6} & \multirow{2}{*}{\multicolumn{2}{|c|}{ Variety mean }} \\
\hline & & 2 & 4 & & & \\
\hline OL & 16.6 & 20.1 & 31.0 & & 21.4 & 22.3 \\
\hline ML & 13.1 & 15.1 & 32.6 & & 24.4 & 21.3 \\
\hline UC82B & 26.6 & 31.6 & 31.1 & & 32.2 & 30.3 \\
\hline Pinching time mean & 18.7 & 22.3 & 31.6 & & 26.0 & \\
\hline
\end{tabular}

LSD 0.05

$\begin{array}{ll}\text { Variety } & 3.89 \\ \text { Pinching time } & 4.49\end{array}$

$\mathrm{V} \times \mathrm{PT} \quad \mathrm{ns}$

$\mathrm{OL}=$ Ogbomoso local, $\mathrm{ML}=$ Mokwa local, $\mathrm{PT}=$ pinching time, $\mathrm{NS}=$ not significant $(\mathrm{P} \leq 0.05), \mathrm{LSD}=$ least significant difference 
Table.3: Effect of variety, pinching time and their interaction on number of fruits per plant of tomato plant in 2012 cropping season

\begin{tabular}{|c|c|c|c|c|c|}
\hline \multicolumn{6}{|c|}{ Number of fruits } \\
\hline \multirow[b]{2}{*}{ Variety } & \multicolumn{4}{|c|}{ Pinching time (WAT) } & \multirow[b]{2}{*}{ Variety mean } \\
\hline & 0 & 2 & 4 & 6 & \\
\hline $\mathrm{OL}$ & 16.6 & 20.1 & 31.0 & 21.4 & 22.3 \\
\hline ML & 13.1 & 15.1 & 32.6 & 24.5 & 21.3 \\
\hline UC82B & 26.4 & 31.6 & 31.8 & 32.2 & 30.5 \\
\hline Pinching time mean & 18.7 & 22.3 & 31.8 & 26.0 & \\
\hline \multicolumn{6}{|l|}{ LSD 0.05} \\
\hline Variety & 4.04 & & & & \\
\hline Pinching time & 4.66 & & & & \\
\hline V x PT & ns & & & & \\
\hline
\end{tabular}

$\mathrm{OL}=$ Ogbomoso local, $\mathrm{ML}=$ Mokwa local, $\mathrm{PT}=$ pinching time, $\mathrm{NS}=$ not significant, $(\mathrm{P} \leq 0.05), \mathrm{LSD}=$ least significant difference

Table.4: Effect of variety, pinching time and their interaction on total fruit yield ( $\mathrm{t}$ ha $\left.{ }^{-1}\right)$ of tomato plant in 2012 cropping season

\begin{tabular}{|c|c|c|c|c|c|c|c|}
\hline \multicolumn{8}{|c|}{ Total fruit yield $\mathrm{t} \mathrm{ha}^{-1}$} \\
\hline \multirow[b]{2}{*}{ Variety } & \multicolumn{6}{|c|}{ Pinching time (WAT) } & \multirow[b]{2}{*}{ Variety mean } \\
\hline & 0 & 2 & 4 & & 6 & & \\
\hline $\mathrm{OL}$ & 10.9 & 14.5 & & 17.6 & & 15.2 & 14.6 \\
\hline ML & 8.3 & 11.1 & & 15.2 & & 13.4 & 12.0 \\
\hline UC82B & 18.2 & 22.8 & & 26.1 & & 25.4 & 23.1 \\
\hline Pinching time mean & 12.5 & 16.1 & & 19.6 & & 18.0 & \\
\hline \multicolumn{8}{|l|}{ LSD 0.05} \\
\hline Variety & 2.95 & & & & & & \\
\hline Pinching time & 3.40 & & & & & & \\
\hline $\mathrm{V} \times \mathrm{PT}$ & ns & & & & & & \\
\hline
\end{tabular}


Table.5: Effect of pinching time on fruit nutritional qualities of protein, carotene and iron of three tomato varieties Nutritional quality $(\mathrm{mg} / 100 \mathrm{~g})$

Pinching time (WAT)

\begin{tabular}{llllll} 
Variety & 0 & 2 & 4 & 0 & Variety Mean \\
\hline & & \multicolumn{5}{c}{ Protein } \\
OL & 1.0 & 1.0 & 1.0 & 1.0 & 1.0 \\
ML & 1.1 & 1.1 & 1.1 & 1.1 & 1.1 \\
UC82B & 1.1 & 1.1 & 1.1 & 1.1 & 1.1 \\
PT Mean & 1.1 & 1.1 & 1.1 & 1.1 & \\
LSD:V & 0.01 & & & & \\
PT & $n s$ & & & & \\
V x PT & $n$ ns & & &
\end{tabular}

\begin{tabular}{llllll} 
& \multicolumn{3}{c}{ Carotene } \\
OL & 0.2 & 0.3 & 0.4 & 0.4 & 0.3 \\
ML & 0.2 & 0.3 & 0.4 & 0.4 & 0.3 \\
UC82B & 0.2 & 0.3 & 0.5 & 0.5 & 0.4 \\
PT Mean & 0.2 & 0.3 & 0.4 & 0.4 & \\
LSD:V & ns & & &
\end{tabular}

$\begin{array}{ll}\text { PT } & 0.11 \\ \text { V x PT } & \text { ns }\end{array}$

Iron

$\begin{array}{llllll}\text { OL } & 0.6 & 0.7 & 0.7 & 0.7 & 0.7 \\ \text { ML } & 0.5 & 0.7 & 0.6 & 0.6 & 0.6 \\ \text { UC82B } & 0.4 & 0.6 & 0.7 & 0.8 & 0.6 \\ \text { PT Mean } & 0.5 & 0.7 & 0.7 & 0.7 & \end{array}$

$\begin{array}{lll}\text { LSD:V ns } & \text { nT } \\ \text { PT } & \text { ns }\end{array}$

$\mathrm{V} \times \mathrm{PT} \quad \mathrm{ns}$

$\mathrm{OL}=$ Ogbomoso local, $\mathrm{ML}=$ Mokwa local, $\mathrm{V}=$ variety, $\mathrm{PT}=$ pinching time, $\mathrm{NS}=$ not significant, $(\mathrm{P} \leq 0.05), \mathrm{LSD}=$ least significant difference

Table.6: Effect of pinching time on fruit nutritional qualities of phosphorus, potassium and calcium of three tomato varieties Nutritional quality $(\mathrm{mg} / 100 \mathrm{~g})$

Pinching time (WAT)

\begin{tabular}{llllll} 
Variety & 0 & 2 & 4 & 6 & Variety Mean \\
\hline OL & 6.7 & 7.6 & 8.1 & 8.0 & 7.6 \\
ML & 6.0 & 6.4 & 7.0 & 6.9 & 6.6 \\
UC82B & 6.7 & 7.0 & 7.5 & 7.2 & 7.1 \\
PT Mean & 6.5 & 7.0 & 7.5 & 7.4 & \\
LSD:V & 0.05 & & & \\
PT & 0.06 & & & & \\
V x PT & 0.03 & & & & \\
& & & & \\
OL & 4.1 & 4.5 & 5.4 & 5.5 & 5.9 \\
ML & 4.6 & 5.6 & 6.3 & 5.8 & 5.3 \\
UC82B & 4.4 & 5.4 & 5.8 & 5.7 & \\
PT Mean & 4.4 & 5.2 & 5.8 & 5.7 & \\
LSD:V & 0.04 & & & & \\
PT & 0.05 & & & & \\
\hline
\end{tabular}


V x PT

ns

OL

ML

7.3

UC82B

PT Mean

7.2

LSD:V

PT

9.2

7.9

0.11

0.12

$\mathrm{V} \times \mathrm{PT}$ 0.01

$\mathrm{OL}=$ Ogbomoso local, $\mathrm{ML}=$ Mokwa local, $\mathrm{V}=$ variety, $\mathrm{PT}=$ pinching time, $\mathrm{NS}=$ not significant, $(\mathrm{P} \leq 0.05), \mathrm{LSD}=$ least significant difference

Table.7: Effect of pinching time on fruit nutritional qualities of lycopene, magnesium and vitamin C of three tomato varieties Nutritional quality $(\mathrm{mg} / 100 \mathrm{~g})$

\begin{tabular}{|c|c|c|c|c|c|}
\hline \multirow[b]{3}{*}{ Variety } & \multicolumn{5}{|c|}{ Nutritional quality $(\mathrm{mg} / 100 \mathrm{~g})$} \\
\hline & \multicolumn{5}{|c|}{ Pinching time (WAT) } \\
\hline & 0 & 2 & 4 & 6 & Variety Mean \\
\hline & \multicolumn{5}{|c|}{ Lycopene } \\
\hline OL & 1.5 & 1.7 & 2.0 & 2.2 & 1.9 \\
\hline ML & 1.3 & 1.8 & 2.1 & 2.1 & 1.8 \\
\hline UC82B & 1.5 & 1.7 & 2.0 & 1.9 & 1.8 \\
\hline PT Mean & 1.4 & 1.7 & 2.0 & 2.1 & \\
\hline LSD:V & ns & & & & \\
\hline PT & $\mathrm{ns}$ & & & & \\
\hline \multirow[t]{2}{*}{$\mathrm{V} \times \mathrm{PT}$} & ns & & & & \\
\hline & \multicolumn{5}{|c|}{ Magnesium } \\
\hline $\mathrm{OL}$ & 0.4 & 0.6 & 0.7 & 1.1 & 0.7 \\
\hline ML & 0.4 & 0.5 & 0.7 & 0.8 & 0.6 \\
\hline UC82B & 0.6 & 0.7 & 0.8 & 0.6 & 0.7 \\
\hline PT Mean & 0.5 & 0.6 & 0.7 & 0.8 & \\
\hline LSD:V & ns & & & & \\
\hline PT & 0.16 & & & & \\
\hline \multirow[t]{2}{*}{$\mathrm{V} \times \mathrm{PT}$} & ns & & & & \\
\hline & \multicolumn{5}{|c|}{ Vitamin C } \\
\hline $\mathrm{OL}$ & 26.8 & 29.3 & 32.8 & 31.0 & 30.0 \\
\hline ML & 28.0 & 29.2 & 31.0 & 30.7 & 29.7 \\
\hline UC82B & 29.3 & 31.8 & 34.5 & 33.5 & 32.3 \\
\hline PT Mean & 28.0 & 30.1 & 32.8 & 31.7 & \\
\hline LSD:V & 1.15 & & & & \\
\hline PT & 1.32 & & & & \\
\hline $\mathrm{V} \times \mathrm{PT}$ & ns & & & & \\
\hline
\end{tabular}

